OLIVERA ILIĆ

Institute of Archaeology

Belgrade, Serbia

E-mail: o.ilic@ai.ac.rs
UDC 904"652"(497.11)

94:63(398)

Original research article

Received: $5^{\text {th }}$ September 2019

Accepted: $15^{\text {th }}$ November 2019

\title{
ROMAN AGRICULTURE: A CASE STUDY FROM VIMINACIUM AND ITS SURROUNDINGS
}

\begin{abstract}
This paper is a brief overview of the research at Viminacium and in its surroundings performed so far that are related to agricultural activities. Aside from villae rusticae, which were registered in large numbers within the ager of the city, the discoveries of which have broadened our knowledge on the subject in the last few years, numerous archaeological remains of farming tools from various locations in Viminacium indicate the existence of larger agricultural estates of the municipal aristocracy. Archaeobotanical analyses have a special importance, because they show if there were any changes in regional vegetation, which, in turn, can point towards a continuity or discontinuity in the settling of a given region.
\end{abstract}

KEYWORDS: AGRICULTURAL PRODUCTION, VILLAE RUSTICAE, AGRICULTURAL TOOLS, ARCHAEOBOTANICAL ANALYSES, VIMINACIUM, ROMAN PERIOD.

Agriculture was a fundamental activity of the Balkan indigenous population, even before these territories fell under the Roman domination. The new Roman reign brought new organisation methods, more or less successfully including the local population, which depended on the Romanisation level of the newly established Roman provinces. Therefore, the reconstruction of agriculture in all its aspects represents one of the main factors for the understanding of the course of Roman influence in provinces formed in these areas. ${ }^{1}$

Until recently, little was known about the agricultural activities in Viminacium and its surround-

1 The article is a result of the project: Viminacium, Roman city and military camp - research of the material and non material culture of inhabitants by using the modern technologies of remote detection, geophysics, GIS, digitalization and $3 D$ visualization (no 47018), funded by The Ministry of Education, Science and Technological Development of the Republic of Serbia. ings during the Roman period. The last few years of research in this area, however, have expanded the knowledge on the importance of rural economy. We can, therefore, speak of farming as a basic economic activity which lead to the development and significant prosperity of the city, especially during the $2^{\text {nd }}$ and $3^{\text {rd }}$ century AD.

During a field survey of the route of the Antique road between Viminacium and Lederata in 2003-2004, archaeologists from the National Museum of Požarevac, Dragana Spasić-Đurić and Dragan Jacanović, recognised the problem of insufficient research and study of content related to every-day life outside the urban part of the city (Spasić-Đurić, Jacanović 2007: 123-164). By locating the route of the road and registering sites on the left and the right side of the road, they provided a solid foundation to grasp, through analyses 


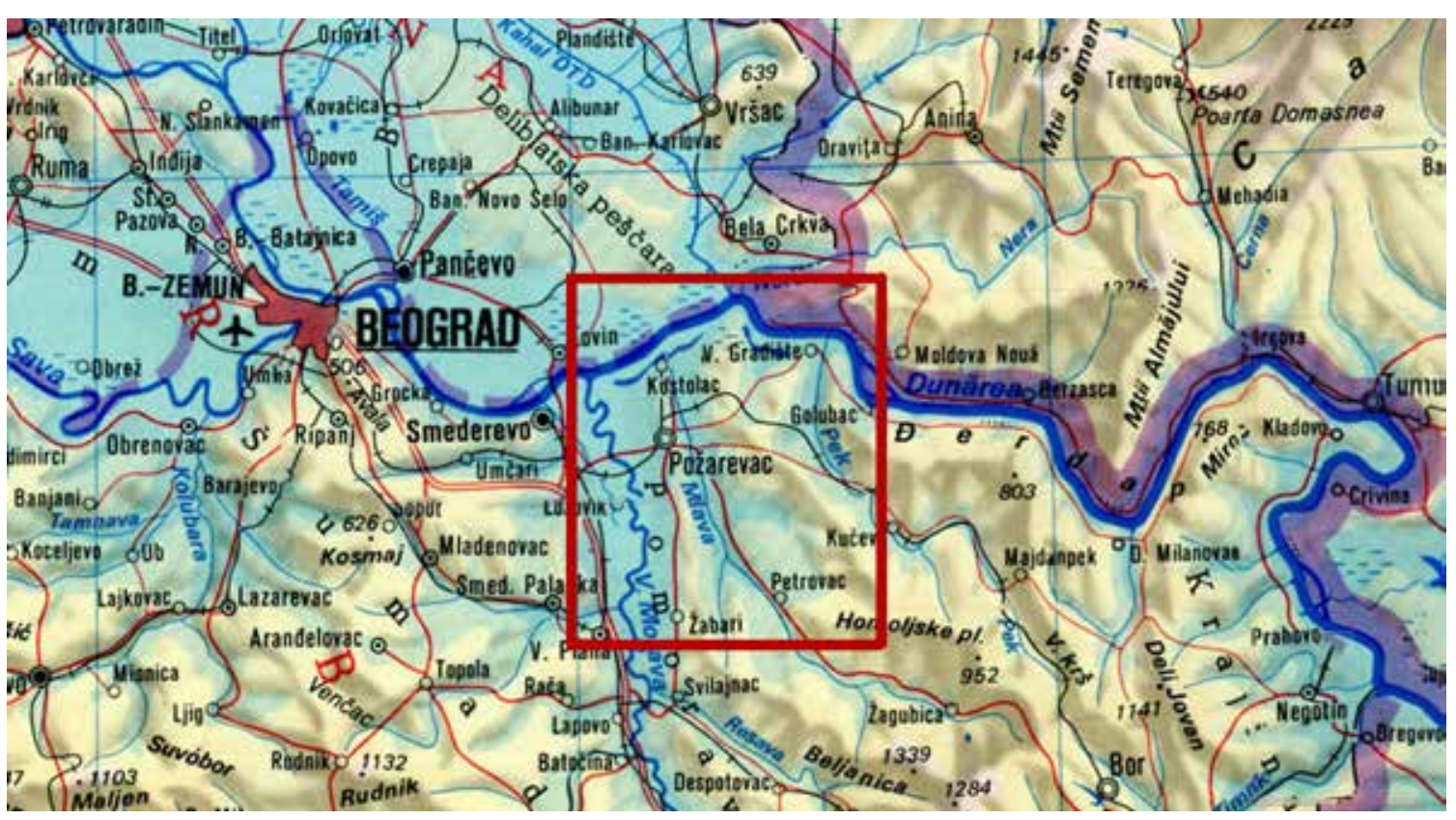

Map 1 - The area of Stig plain.

of topographic data and archaeological finds, the actual scope of ancient Viminacium and its spatial organisation.

The marginalisation of topics regarding rural settlements (vici, villae rusticae), economics of agricultural estates, changes in the demographic structure, socio-economic aspects of life, etc. has been partially reduced in the last few years through discoveries of villas on several sites in the wider area of the city territory of Viminacium (Jovičić, Redžić 2012: 369-385). These discoveries in the immediate urban surroundings are indicative of the importance of agriculture to the inhabitants of Viminacium, but they still do not provide answers to questions related to the scope and structure of the ager of Viminacium.

Also worth mentioning is an article by A. Medović, which provided results of the archaeobotanical analyses obtained during archaeological research in Viminacium performed after 2000. Even though the main goal of these archaeobotanical analyses was to show which type of timber was used for the construction of the amphitheatre, the results obtained showed, among other things, a richness of cereals and weeds at the site, which indicated intensive farming production on the wider territory of the city (Medović 2014: 95-99, T. I).

The ancient city and military camp of Viminacium was situated in the fertile plains of Stig. When the city had the status of a municipium (117 AD), its territory covered a larger part of the plain in the lower course of the Mlava River, on the Stig plain while, after acquiring the status of a colony (239 AD), Viminacium expanded to cover the entire Stig plain and Veliko Gradište (Pincum) (Popović 1968: 30).

The area of Stig was a very important agrarian area in Antiquity, just as it is today. It is the second largest plain in Serbia, with its northern border the Danube, to the west the Mlava and in the east and south-east the Homolje mountain range (Map 1). The fertile valley at the confluence of the Mlava and the Danube provided conditions for intensive settling activity in this area during prehistory, as well as later, during Antiquity. The valley of the Dunavac often flooded, thus creating fertile ploughland, providing suitable living conditions which, in turn, resulted in dense settling in this area. Good communications with other city centres, first and foremost with Singidunum, on one side, and the Morava river valley on the other, together with the fortification system along the Danubian limes, 


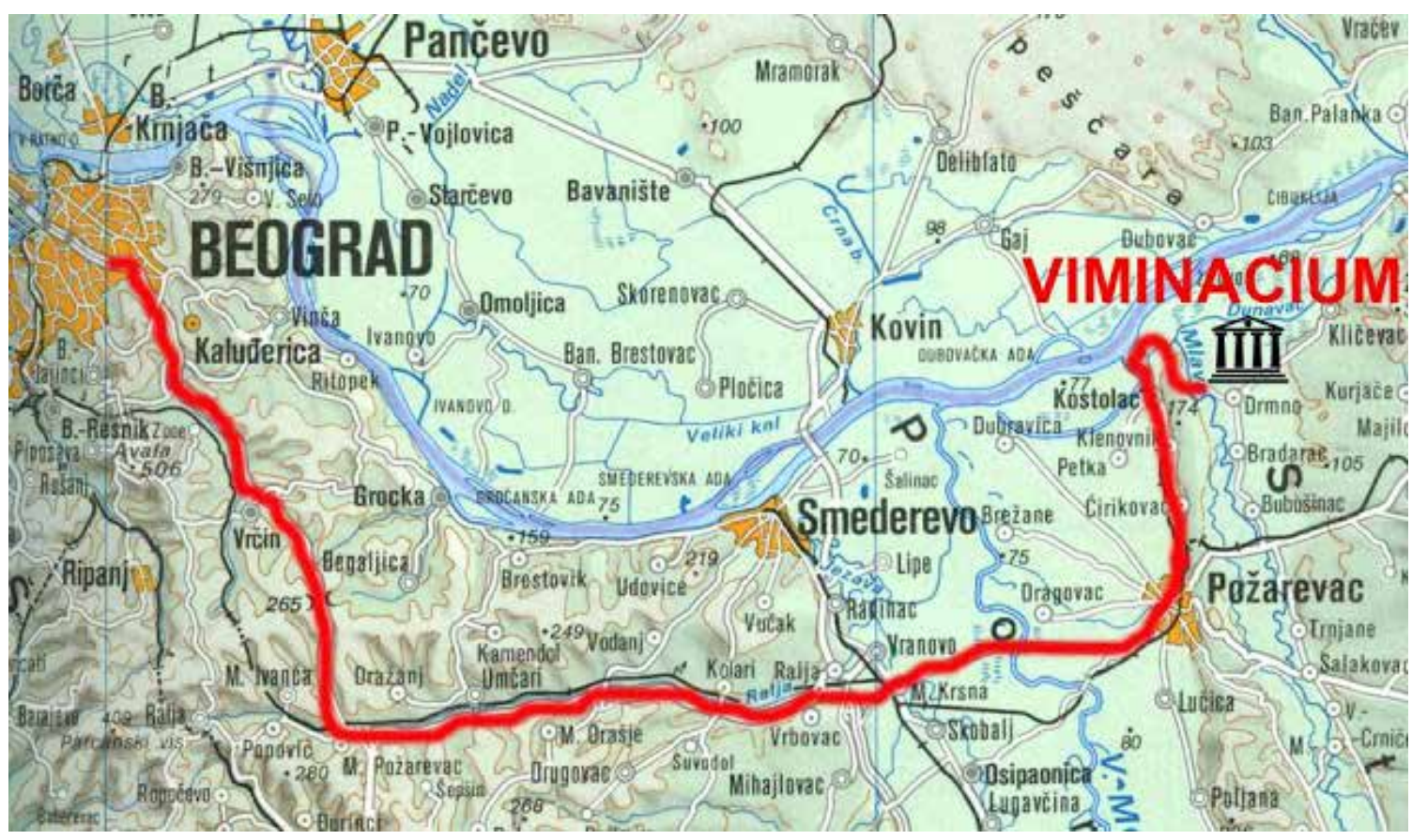

Map 2 - Roman road Singidunum-Viminacium.

enabled the continuous transit of merchandise and safe markets (Map 2).

In order to obtain more reliable data on the development of Roman agriculture in the wider area of Viminacium, it is necessary to perform extensive research, starting with climate, relief, soil, and archaeobotanical analyses.

Concerning climate change in the Roman period, we know that, at the beginning of the 1st millennium $\mathrm{AD}$, climatic conditions in some parts of Europe were not the same as today. The Climatic Optimum of the Roman period was reached in the 1 st century AD. The average annual temperature in Europe was higher than today by $1-1.5^{\circ} \mathrm{C}$. According to research, the Alps were green in that period and the boundary of the glacier was at least $300 \mathrm{~m}$ higher than today (Schlüchter 2004: 34-47).

As the period for which there is available meteorological data is brief, historical information regarding migrating plant species should be considered. By tracking the history of vegetation, it can be established whether the climate changed and, if so, when this happened. As evidence of this, data shows that, in the early Middle Ages, the inhab- itants of Greenland were still engaged in animal husbandry and farming, and that cooling started at some point in the 13th century (Opra 1998: 166). However, this change in the average annual temperature of the Earth is not accompanied by uniform changes in all parts of the globe. Regarding global climate variations, the changes were greater in areas closer to the poles. Usually, major changes in the climate of regions with a higher latitude are followed by the moving of the borders of plants and the withdrawal of animals from these regions to areas with warmer climates, or vice versa.

Based on paleobotanical research, it can be concluded that the climate in the Mediterranean has been stable for the last few thousand years. Consequently, the southern border of the grape growing region and the olive growing region's northern border have not changed since biblical times. According to scientific knowledge, the northern border of the region of olive cultivation in Italy is in the same place today as it was during the ancient period (Opra 1998, 165). From data on global climate variations and its change around Greenland and its stability in the Mediterranean, 


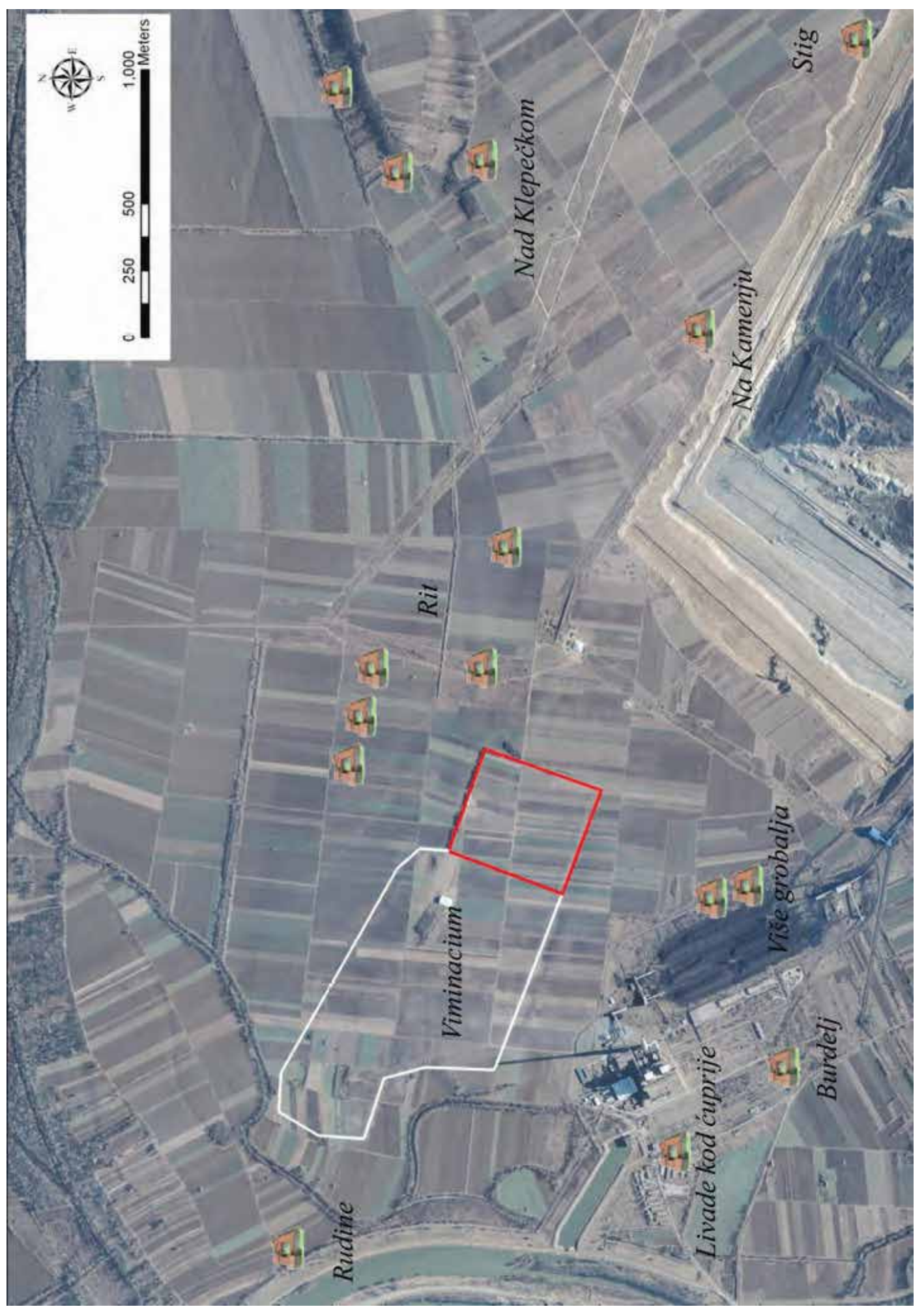

nothing can be concluded regarding climate variations in the area of the Central Balkans. Grapes and chestnuts are characteristic of hot regions. Oak thrives in colder areas and can withstand very low temperatures, but bears little fruit. According to historical data, oak forests existed in the Balkans before the arrival of the Romans. The 5th century Byzantine historian Priscus speaks 
of dense woods north of Naissus (Острогорски 1955, Прискос, Фрг. 8: 291). The fruits of the forest are used for animal feed, but also for people. Bearing in mind the presence of these cultures today, we can conclude that the climate in the Balkans has not changed much in the last two thousand years.

Several decades long rescue excavations of the Antique city of Viminacium have brought to light a large number of findings with a variety of functions. Since the archaeological excavations are conditioned by the works on the Drmno surface mine, the discoveries of city necropoles and other urban structure have provided the most visible results so far. However, in the last few years the scope of research has been broadened into the wider area of the city territory, which has resulted in very the important discoveries of several villas. The founding of agricultural estates outside of the city is linked to the period of economic prosperity during the 2 nd and the first half of the 3rd century, when most of the inhabitants of the wider city territory lived and worked on them. Relative political security in this period enabled, among other things, the development of farming, which represented one of the basic activities in the area of the fertile plain of Stig in the province of Moesia Superior. In an indirect manner, dedications to agricultural deities also bear witness to this fact: to Liber and Libera (Pilipović 2006: 89; Mirković 1986: 73, no. 27) and Silvanus (Mirković 1986: 198, no. 300).

This remarkably favourable micro-unit represented an ideal place for agricultural estates of the villa rustica type with the farm buildings and manufacturing workshops necessary on such homesteads. As the political, military, economic and religious centre of a wider territory, the city certainly depended on its rural area, which represented the basic source of food for the city population. The remains of villas have been discovered at various locations within the city ager in the course of archaeological research at Viminacium in recent years (Jovičić, Redžić 2012: 369-385: Korać, Golubović, Mrđić 2018: 41-71), (Fig. 1).
A confirmation of intensive farming activities in the wider city area of Viminacium can also be seen with the finds of farming tools, discovered in various different locations. These are mostly tools used in farming production: spades, sickles, billhooks, picks, mattocks, axes and pickaxes (Fig. 2, 3). The finding conditions show that a large number of these tools have been present at locations where objects intended for farming activities were registered. ${ }^{2}$

The agricultural orientation of the area of Viminacium required a large number of people to work on the land. It is probable that the workforce consisted mostly of free peasants at first, who lived on the estates or in their vicinity. In this context, it should be mentioned that the role of the free peasants/tenants has yet to be defined, and all the information related to this topic is based on assumptions. The peasants/tenants most probably cultivated the land of the municipal aristocracy, but afterwards, with the progress of Romanisation, their numbers diminished, first and foremost because of their ever increasing participation in military service. We may, therefore, assume that the use of a slave workforce increased. This is supported by epigraphic data from the 3rd century, where it is stated that when land was assigned to soldiers, they would also receive, at the same time, slaves and cattle (Mirković 1968: 138, note 14).

More information on the development of farming activities in the wider city territory of Viminacium is also provided by the results of archaeobotanical analyses performed within archaeological research in the last few years (Medović 2014: 95-99). On the basis of results obtained from Viminacium, together with other sites in Serbia from which earth samples have been taken, it is possible to enumerate all the important cereals which were grown in the Roman period (Medović 2008: 151-173; Medović 2010: 101-113). The first analyses have shown that the area around

2 An especially large number of farming tools has come from the site of Nad Klepečkom, where a large villa was registered. 


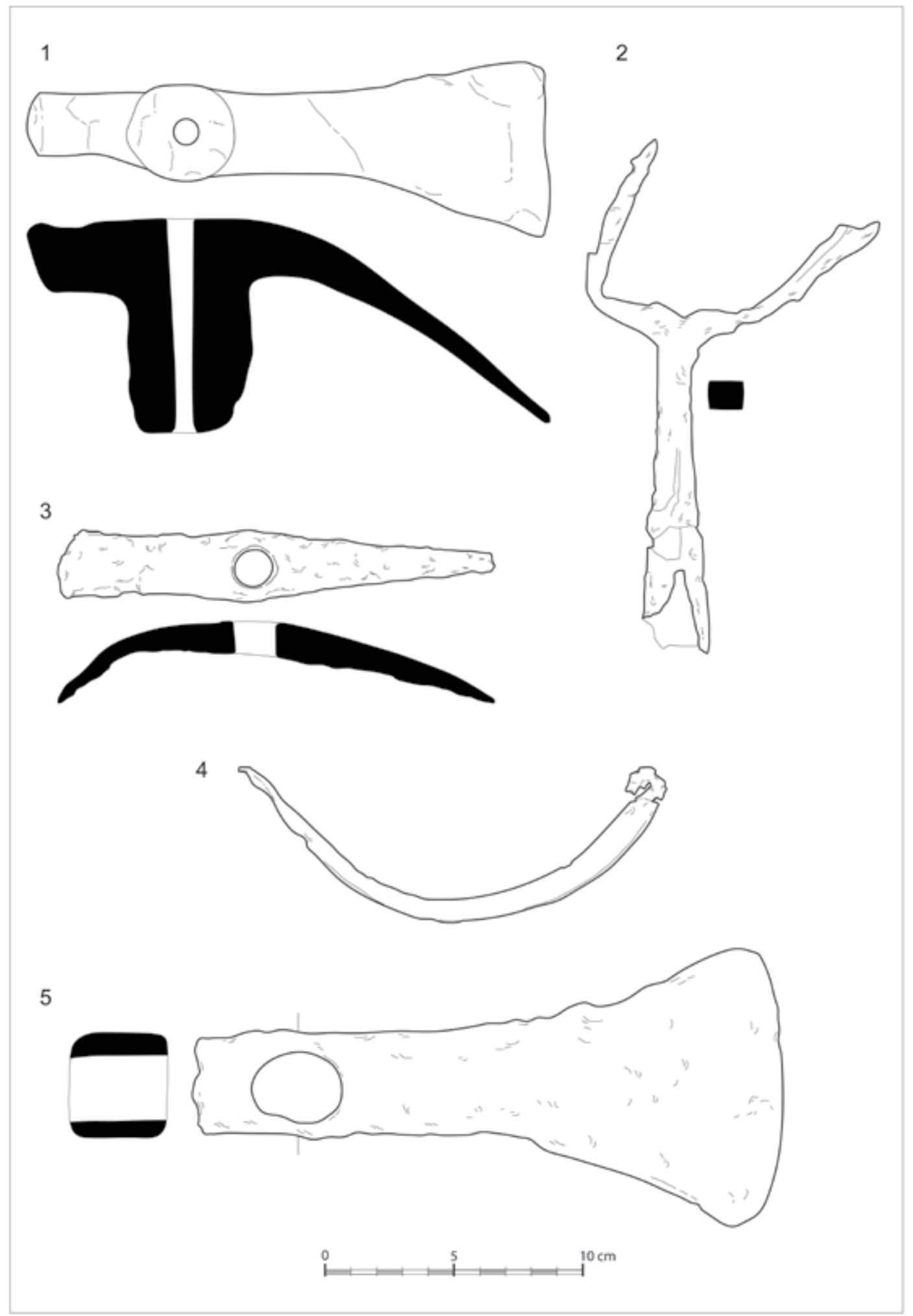

Fig. 2 -Agricultural tools from the sites: 1, 2, 4, 5 - Nad Klepečkom; 3 - Pećine (Doc. of the Institute of Archaeology, Belgrade, Project Viminacium, drawings). 


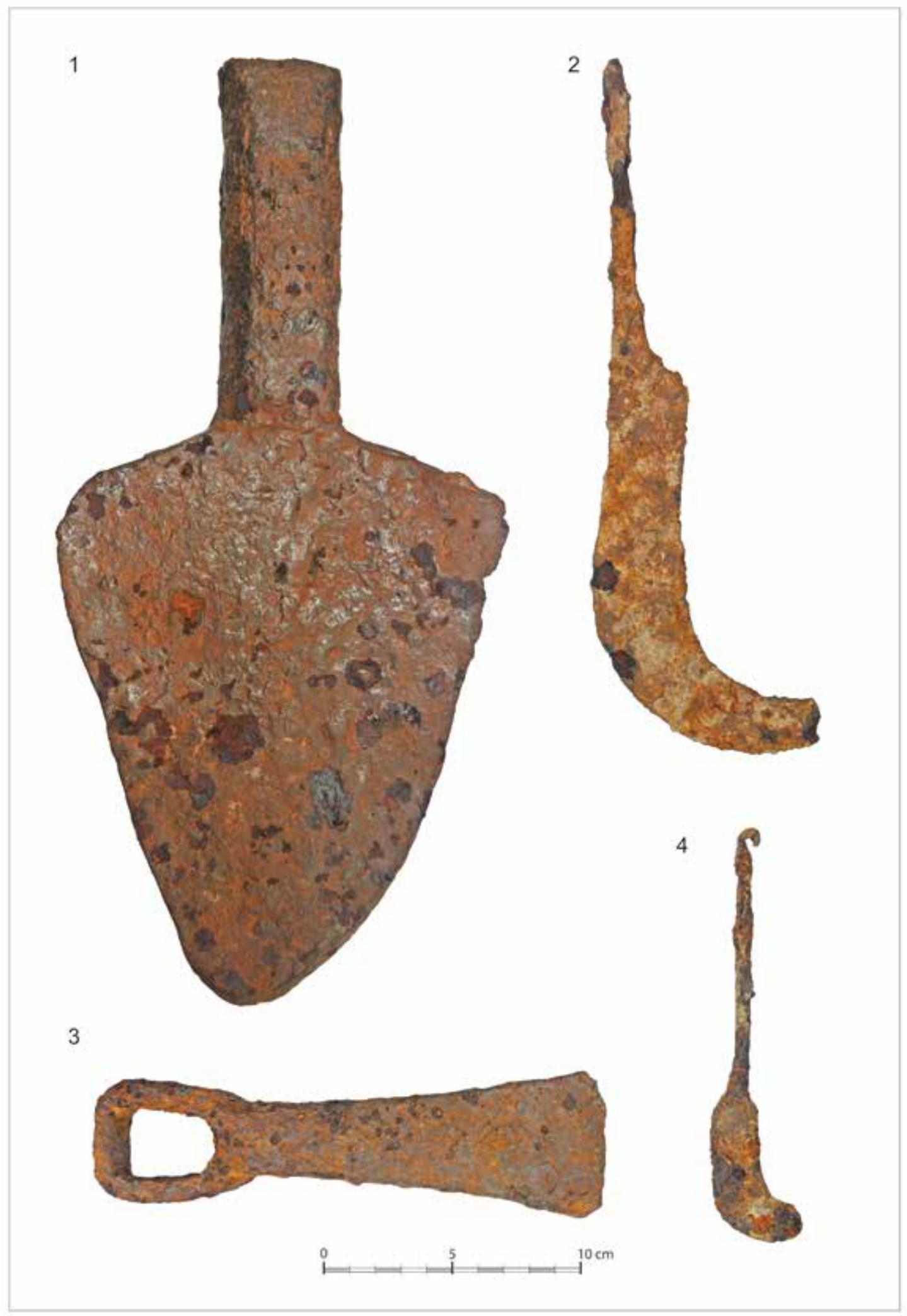

Fig. 3 -Agricultural tools from the sites: 1 - Burdelj; 2 - Rit; 3, 4. - Nad Klepečkom (Doc. of the Institute of Archaeology, Belgrade, Project Viminacium, photos). 
Viminacium was very suitable for plant economy. Even though the main goal of these archaeobotanical analyses was to show which type of timber had been used for the construction of the amphitheatre, the analysis provided data on the presence of cereals and weeds as well. The results showed the presence of five cereals (loose six-row barley, rye, bread wheat, oats and broomcorn millet) and one cultivated pulse crop, lentil. Three fruit species were identified: woodland strawberries (Fragaria vesca), hazel (Corylus avellana) and common fig (Ficus carica). The list of weeds includes 25 plant names (Medović 2014: 97, T.1). All of these plants, with the exception of millet, can be seen even today in the ploughland of the valley of Stig. This ancient crop was suppressed, over a just a few centuries, by maize and, thus, virtually vanished from ploughlands.

These types of analyses has a special importance, for they can show if there had been any changes in the regional vegetation, which, in turn, could point to a continuity or discontinuity in the settling and usage of a given area.

\section{CONCLUSION}

Even though we are still far from having a complete overview of the actual scope and structure of the ager of Viminacium, the more recent research of the wider city territory does shed, however, a new light on the pre-existing knowledge on agricultural activities and the importance of the rural economy in providing provisions for the city population of Viminacium during the Roman period. Through analyses of available material we can conclude that agriculture played an important role in the wider territory of Viminacium. Aside from villae rusticae, which were registered in large numbers within the city ager, the development and improvement of tools intended for the cultivation of cereals certainly had an influence on the intensity of agricultural production and increase in yields. Additionally, numerous archaeological remains of agricultural tools at various locations in Viminacium suggest the existence of larger agricultural estates of the municipal aristocracy, on which the autochthonous free population of the area was most probably hired at first, although over time, with the progress of Romanisation, the number of free peasants who worked the land gradually decreased, since a large part of the Roman army was recruited from within their ranks. Thus, we may assume that, over time, the usage of a slave workforce increased.

Numerous archaeological remains of agricultural tools at different locations in Viminacium and throughout the territory of Stig indicate the existence of estates of landowners, a fact that is entirely understandable given that the fertile Stig plain was suitable for farming, especially for growing grains. Furthermore, these remains are similar to the tools recorded in the fortifications on the Danube Limes in the province of Moesia Superior (Ilić 2016: 31-42; Поповић 1988: 33108). This indicates the importance of the production of grain as the basic food intended for the inhabitants of Viminacium, but also the military stationed in the castrum of Viminacium and in the numerous fortresses along the Danube.

Finally, we can say that there has been a tendency in the recent years among the investigators of the archaeological site of Viminacium to carry out a more detailed analysis of the mentioned villas, but also the other objects used in agriculture, including topographic and typological determinations. However, it seems that some even more comprehensive studies are still required.

\section{$* * *$}

Arheologija i prirodne nauke (Archaeology and Science) is an Open Access Journal. All articles can be downloaded free of charge and used in accordance with the licence Creative Commons - Attribution-NonCommercial-NoDerivs 3.0 Serbia (https://creativecommons.org/licenses/ by-nc-nd/3.0/rs/. 
Časopis Arheologija i prirodne nauke je dostupan u režimu otvorenog pristupa. Članci objavljeni u časopisu mogu se besplatno preuzeti sa sajta i koristiti u skladu sa licencom Creative Commons - Autorstvo-Nekomercijalno-Bez prerada 3.0 Srbija (https://creativecommons.org/licenses/bync-nd/3.0/rs/.

\section{BIBLIOGRAPHY}

\section{Ilić, O. 2016}

Finds of Roman Agricultural Tools on the Danubian Limes in Upper Moesia as Indicators of Agricultural Development in the Area of Military Camps, Archaeology and Science (Arheologija $i$ prirodne nauke) 11 (2015): 31-42.

\section{Jovičić, M. and Redžić, S. 2012}

Late Roman Villa on the Site Livade kod Ćuprije A Contribution to the Study of Villae Rusticae in the Vicinity of Viminacium, Archaeology and Science (Arheologija i prirodne nauke) 7 (2011): 369-385.

\section{Korać, M., Golubović, S. and Mrđić N. 2018}

Research of Viminacium and its Suburban Zones, Vivere Militare Est: From Populus to Emperors Living on the Frontier, Vol. 2, Belgrade: Institute of Archaeology: 41-71.

\section{Medović, A. 2008}

Gamzigradski ratari - dva koraka napred, jedan korak nazad, $P M B$ 50: 151-173.

\section{Medović, A. 2010}

„Arheoznanje - arheoimanje“ u poseti jednom sremačkom vikusu iz I ili II veka, PMB 52: 101111.

\section{Medović, A. 2014}

Viminacium: Roman agriculture of Serbian soil?, Archaeology and Science (Arheologija i prirodne nauke) 9 (2013): 95-99.

\section{Mirković, M. 1968}

Rimski gradovi na Dunavu u Gornjoj Meziji, Beograd: Arheološko društvo Jugoslavije.

\section{Mirković, M. 1986}

Viminacium et Margum, Inscriptions de la Mésie Supérieure, vol. II, Beograd: Centre d'études épigraphiques et numismatiques de la Faculté de philosophie de l'Universite de Belgrade.

\section{Опра, Љ. 1998}

Девет храстова: записи о историји српске метеорологије, Београд, Флогистон: Музеј науке и технике САНУ, Републички хидрометеоролошки завод.

(Opra, LJ. 1998

Devet hrastova: zapisi o istoriji Srpske meteorologije, Beograd, Flogiston: Muzej nauke i tehnike SANU, Republički hidrometeorološki zavod.)

\section{Острогорски, Г. (ур.) 1955}

Византијски извори за историју народа Југославије I, Београд: САН Посебна издања.

(Ostrogorski, G. (ur.) 1955

Vizantijski izvori za istoriju naroda Jugoslavije I, Beograd: SAN Posebna izdanja.)

\section{Pilipović, S. 2006}

Votive Relief from Barovo (Scupi), Starinar LV/2005: 81-95.

\section{Поповић, И. 1988}

Античко оруђе од гвожђа у Србији, Београд: Народни музеј, Београд.

(Popović, I. 1988

Antičko oruđe od gvožđa u Srbiji, Beograd:

Narodni muzej, Beograd.)

\section{Поповић, В. 1968}

Увод у топографију Виминацијума, Старинар

XVIII/1967: 29-53.

(Popović, V. 1968

Uvod u topografiju Viminacijuma, Starinar XVIII/1967: 29-53.) 
Schlüchter, Ch. und U. Jörin 2004

Alpen ohne Gletscher? Holz und Torffunde als Klimaindikatoren, Die Alpen 6, 2004, 34-47.

Спасић-Ђурић, Д. и Јацановић, Д. 2007

Траса пута Виминацијум-Ледерата резултати микрорекогносциранња у 2003-2004. г

Viminacium 15: 123-164.

(Spasić-Đurić, D. i Jacanović, D. 2007

Trasa puta Viminacijum-Lederata rezultati mikrorekognoscirannja u 2003-2004. g

Viminacium 15: 123-164.)

\section{REZIME}

RIMSKA POLJOPRIVREDA:

PRIMER VIMINACIJUMA I NJEGOVE OKOLINE

KLJUČNE REČI: POLJOPRIVREDNA PROIZVODNJA, VILLAE RUSTICAE, POLJOPRIVREDNA ORUĐA, ARHEOBOTANIČKE ANALIZE, VIMINACIUM.

Novija istraživanja šire gradske teritorije Viminacijuma daju novu svetlost na dosadašnja saznanja o poljoprivrednoj aktivnosti i značaju ruralne ekonomije u snabdevanju gradskog stanovništa Viminavcijuma tokom rimskog perioda.
Pored vila rustika koje su konstatovane u većem broju u okviru gradskog agera, razvoj i usavršavanje oruđa namenjenog kultivaciji žitarica uticali su, svakako, na intenzitet poljoprivredne proizvodnje i povećanje prinosa. Brojni ostaci poljoprivrednog oruđa na različitim lokacijama $u$ Viminacijumu i njegovoj okolini, ukazuju na postojanje većih poljoprivrednih imanja municipalne aristokratije, što je sasvim razumljivo imajući u vidu činjenicu da areal Stiga obuhvata jednu plodnu ravnicu pogodnu za poljoprivrednu proizvodnju, naročito za uzgoj žitarica, što je potvrđeno i arheobotaničkim analizama. Ovakve analize imaju poseban značaj, jer mogu da pokažu da li je dolazilo do promena u regionalnoj vegetaciji, a koje bi dalje mogle da ukažu na kontinuitet ili diskontinuitet $u$ naseljavanju šireg područja Viminacijuma tokom čitavog perioda rimske dominacije. 